\title{
The Role of Consumer- Brand Experiences and Relationship in Contributing to Brand Equity for Services
}

\author{
By Lai-cheung Leung*
}

\begin{abstract}
Branding today is conceived as a co-creation process during which brand equity is created through interactions among the stakeholders and personalized consumer experience is an important branding practice for value creation and differentiation from competitors. Consumer-brand relationship has been proposed as a metaphor to connect relationship marketing activities and brand equity. However, little research has been conducted to examine how experiences with a brand affect brand equity via the consumer-brand relationship, especially in a service context. This research aims at developing a conceptual model to depict the structural relationships among brand experiences, consumer-brand relationship and brand equity. The model was tested against a student sample and received reasonable support. The utilitarian brand relationships, as different from a number of previous studies, contribute more to brand equity than affective brand relationships. Marketing implications, research limitations and future research directions are discussed at the end of the paper.
\end{abstract}

Keywords: Brand equity, Brand experiences, Consumer-brand relationship, Services branding.

\section{Introduction}

Given the paradigm shift in marketing to a service dominant logic (Vargo and Lusch 2004) and the changing role of branding to a co-creation process during which brand value is developed and evolved through interactions among the stakeholders involved (Merz et al. 2009), the consumer experiences in the process are viewed as the basis for brand value creation (Prahalad and Ramaswamy 2000, 2004) and developing a close consumer-brand relationship is proposed as a strategic imperative to foster brand loyalty (Fournier 1998). A number of previous studies confirmed the importance of brand experiences in marketing practice (e.g. Schmitt 1999, Grace and O'Cass 2004, Chang and Chieng 2006, Brakus et al. 2009, Iglesias et al. 2011) and the existence of the consumer-relationship framework (e.g. Sweeney and Chew 2002, Veloutsou 2007). However, only a few studies examined how brand experiences affected brand relationship quality (e.g. Chang and Chieng 2006, Lee and Kang 2012, Morgan-Thomas and Veloutsou 2013). Very little research has been conducted to investigate how brand equity, a measure of brand value in this research, is co-created through brand experiences and consumer-brand relationship,

\footnotetext{
* Senior Lecturer, Department of Marketing and International Business, Lingnan University, Hong Kong.
} 
especially in a service context. The objective of the present research is to investigate how brand experiences affect brand equity for services via the mediating role of consumer-brand relationship. The consumer-brand relationship is conceived as a second order construct comprising affective relationship and utilitarian relationship (Leung et al. 2014) and hypothesized as a mediating variable that connects the branding efforts (measured by brand experiences) and the branding outcomes (measured by brand equity). A conceptual model is developed to depict the relationships among brand experiences, brand relationship and brand equity. It is hoped that the present research could add insights to marketers and academics in understanding the role of brand experiences and brand relationship in co-creating brand equity for services.

\section{Literature Review}

Branding as a communication strategy is to develop perceived differences among competing offers in a consumers' mind and this is done through a longterm communication process consisting of different stages that contribute to brand equity for consumers (Keller 2001). In a service context, the brand equity is resulted from customer experiences during the service encounters (Berry 2000, Grace and O'Cass 2004). This brand communication process comprises one-way and two-way means operating at the corporate, marketing and marketing communication levels (Duncan and Moriarty 1998). A consumer-brand relationship is a construct that recognizes the interactivity between a brand and its consumers (Fournier 1998). Employees' behaviors, consumer participation and their interactions in a service encounter are important elements for consumer satisfaction (de Chernatony and Segal-Horn 2003). The frequent interactions between consumers and their service providers create distinct brand experiences that differentiate from competing offers (Thompson et al. 2006, Merz et al. 2009).

The consumer-brand relationships resulting from distinct brand experiences parallels the evolving service-dominant (S-D) logic in marketing, proposed by Vargo and Lusch (2004) who argued that marketing needed to shift the focus to a service-dominant perspective by emphasizing intangible resources, co-creation of value and relationships (Merz et al. 2009). In fact, Vargo and Lusch (2004: 2) redefined services as "the application of specialized competences (knowledge and skills) through deeds, processes and performances for the benefit of another entity or the entity itself" and claimed that all economies are service economies. According Vargo and Lusch (2004), competitive differentiation may be achieved through establishing brand equity, an intangible resource, based on the perceived value of close relationship between the brand and the consumer, as a result of various branding experiences in creating the value of the relationship (Prahalad and Ramaswamy 2004). Therefore, it is proposed in this research that brand equity for services is enhanced through distinct brand experiences via the mediating role of 
consumer-brand relationship. The following sections review the three key constructs in this study: brand experiences, consumer-brand relationship and brand equity.

\section{Brand Experiences}

Schmitt (1999) refers to brand experiences as events that often result from direct observation and/or participating in the event, whether they are real, dreamlike or virtual. In other words, brand experiences are consumers' response to brand related stimuli during the encounter (Chang and Chieng 2006). Along the same line of thought, Brakus et al. (2009: 53) conceptualized brand experiences as "subjective, internal consumer responses (sensations, feelings, and cognitions) and behavioral responses evoked by brand-related stimuli that are part of a brand's design and identity, packaging, communications, and environments". In making their purchase decisions, consumers are concerned with achieving pleasurable experiences (Schmitt 1999). Over time, the favorable brand experiences develop bonds with consumers that help distinguish the brand from competitors and affect consumer satisfaction and loyalty (Brakus et al. 2009). In fact, various studies have shown that brand experiences affect brand attitude and purchase intention (Zarantonello and Schmitt 2010), commitment and brand loyalty (Iglesias et al. 2011, Lee and Kang 2012).

To assist experiential marketing, Schmitt (1999) identified five types of experiences: sense, feel, think, act and relate experiences. Following Schmitt's classification, Chang and Chieng (2006) regrouped the five different brand experiences into two dimensions: individual experiences (sense, feel and think experiences) versus shared experiences (act and relate experiences). In another study, Brakus et al. (2009) distinguished four dimensions of brand experiences: sensory, affective, behavioral and intellectual experiences. To examine brand experiences in a service branding context, Grace and O'Cass (2004) conducted empirical studies and identified three important consumer experiences in services branding: core service performance, servicescape and employee behaviors. Therefore, Ismail et al. (2011) concluded that brand experience is a multidimensional structure comprising a sensorial component, an emotional component, a cognitive component, a pragmatic component, a lifestyle component and a relational component. To fit with a service context, this study adopted the framework developed by Grace and O'Cass (2004) and measured brand experiences in terms of three elements: core service performance, servicescape and employee behaviors.

\section{Consumer-Brand Relationship}

It becomes increasingly difficult to differentiate a brand from competitors based on functional benefits, especially in a service context (Berry 2000). Keller (2003) suggested that marketers should put more emphasis to the intangible aspects of a brand such as a person, place, thing or even other brands 
that are not directly related to the actual product itself. Aaker (1997) identified five dimensions of brand personality, namely sincerity, excitement, competence, sophistication and ruggedness, to guide how a brand might be personified to match with the human characteristics of the target consumers so that a brand could be made close to consumers. McCracken (1993) called this personification branding approach as an anthropological perspective of branding and suggested that a personified brand could be differentiated from competing offers due to the distinct cultural meanings and the myths attached to the brand. To take a step further, Fournier (1998) extended the interpersonal relationship metaphor into the branding avenue and proposed the notion of a consumer-brand relationship to explain how brand equity might be created by this anthromorphization process. In her research, Fournier treated a brand as a relationship partner and identified six relationship dimensions to measure the consumer-brand relationship strength: love/passion, interdependence, selfconnection, commitment, intimacy and brand partner quality. Along the same line of research, Veloutsou (2007) empirically showed that a brand relationship could be measured by two dimensions: two-way communication and affective exchange. Her findings are consistent with previous research as the two-way communication dimension enhances the interactions between a brand and its consumers to develop distinct brand experiences and co-create brand equity, and the affective exchange resembles the consumers' affective feelings towards the brand.

Since Fournier (1998) first advanced the brand relationship metaphor to investigate the brand leveraging process, research on consumer-brand relationship were increased and marketers started to convince that a strong consumer-brand relationship could have such advantages as reducing the marketing costs, enhancing consumers' ease of access to a brand, acquiring new customers, and finally increasing customer loyalty and brand equity (Smit et al. 2007). Fournier (1998) further distinguished between strong and weak consumer-brand relationship by identifying 15 types of brand relationships spanning over strong and weak bondings. Although marketers are interested to develop enduring consumer-brand relationships, not all relationships can be long-lasting and committed by both parties. Different consumer-brand relationship forms might evolve over time through various processes (MacInnis et al. 2009). Fournier (2009) and Fouriner and Avery (2011) developed a relationship map to delineate the different relationship forms according to two dimensions as defined by relationship strength (ranged from superficial/weak to intense/strong) and relationship rewards (ranged from socio-affective to utilitarian/functional rewards). To go along with the previous findings, this study examined two service categories (fast food vs. banking services) that represented different relationship forms as explained in the section on research method below. Following the study by Leung et al. (2014), this research also conceived consumer-brand relationship as a second order construct consisting of an affective dimension (measured by love/passion, self-connection and interdependence) and a utilitarian dimension (measured by commitment, intimacy and brand partner quality). 


\section{Brand Equity}

Brand equity captures the previous investments in branding so that marketers can plan for the future branding efforts (Keller 2001). Brand equity is also considered a major source of competitive advantages for services by providing credibility and added perceived value to consumers (Bharadwaj et al. 1993). Two major approaches to measure brand equity could be identified in the literature: firm-based (e.g. Aaker 1996) and customer-based (e.g. Keller 1993). This study adopted the customer-based approach and defined brand equity as "consumer perceived brand differences arising from the consumer differential response to the marketing efforts of that brand" (Keller 2013). Aaker (1991) proposed four consumer-based brand equity measures (i.e., loyalty, perceived quality, brand associations, and awareness) that received empirical supports (e.g. Yoo et al. 2001, Netemeyer et al. 2004, Pappu et al. 2005). Awareness, associations and perceived quality measures are antecedents of brand equity while loyalty measures relate to the outcomes of brand equity. As the measures for consumer-brand relationship in this research had already included the concept of brand associations and perceived quality (i.e. the affective and the utilitarian dimensions mentioned previously), this study adopted the outcome measures of brand equity and conceived brand equity as a measure of consumers' perceived competitive superiority of a brand (i.e. consumers' differential response to the marketing efforts of a brand) in terms of two indicators: brand uniqueness and price premium (Netemeyer et al. 2004).

\section{Conceptual Model and Hypotheses}

The literature review suggests that the distinct brand experiences created in consumers' mind differentiate a brand from competing offers. Furthermore, brand experiences evolved via an interaction process between the consumers and their contacts with the service personnel and servicescape develop into a consumer-brand relationship. The strength of the relationship formed determines the competitive superiority of the brand. The relationships among brand experiences, consumer-brand relationship and brand equity are shown in Figure 1. 
Figure 1. The Conceptual Model

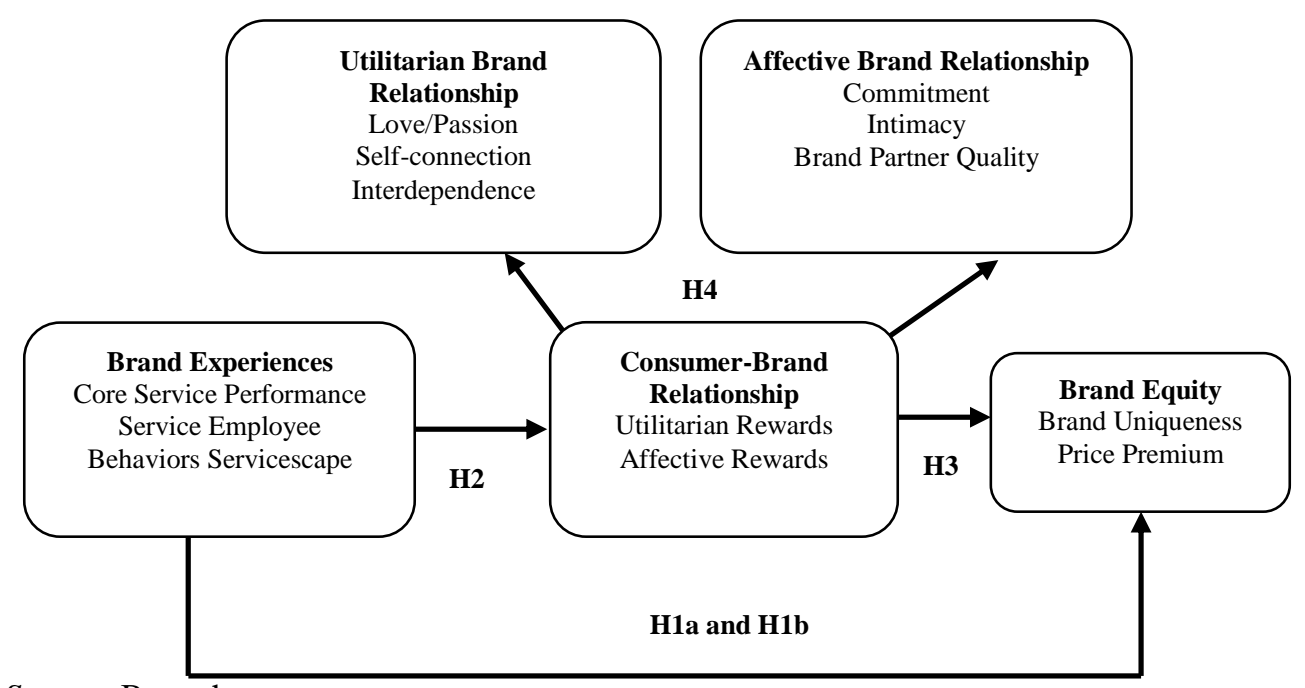

Source: By author.

Few service branding models could be found in the extant literature. Among them, Berry's (2000) model, which followed the seminal study by Keller (1993), suggested that brand equity for services is primarily affected by consumers' experiences in the service process. Furthermore, several studies indicate that brand experiences directly or indirectly affect brand loyalty, a measure of brand equity (e.g. Iglesias et al. 2011, Lee and Kang 2012). Hence,

H1a: The more favorable the brand experiences, the higher the perceived brand equity.

Berry (2000) argued that brand equity is mainly influenced by consumers' experiences in the service process. Therefore, it is important for a marketer to make an affective connection between a service brand and its intended audience to "spark feelings of closeness, affection, and trust" (Berry 2000: 134). Although not explicitly using the relationship metaphor, Berry (2000) recognized the role of the interactivity between consumers and service employees in co-creating brand equity. In another service branding model by de Chernatony and Segal-Horn (2003), the brand experiences resulting from the interactivity between customers and employees in forming the brand relationship were also noted. They proposed that the relationship between a consumer and a service organization is decided by whether the service delivery meets the brand promise in a consistently executed service encounter that develops memorable experiences. The studies by Iglesias et al. (2011) and Lee and Kang (2012) further demonstrated that brand experiences affect brand loyalty directly and indirectly via consumer brand relationship quality. These studies, together with the consumer-brand relationship metaphor proposed by Fournier (1998), suggest that a consumer-brand relationship mediates the relationship between brand experiences and brand equity. Thus,

H1b: Consumer-brand relationship partially mediates the relationship between brand experiences and brand equity. 
Along the line with the consumer-brand relationship metaphor suggested by Fournier (1998), a number of studies investigated how brand relationships were formed. For instance, Chang and Chieng (2006) found that individual and shared experiences resulting from brand associations, brand personality, brand attitude and brand image in a service process determined the strength of a consumer-brand relationship. Iglesias et al. (2011) and Lee and Kang (2012) revealed that brand experiences affected brand relationship. These previous studies on services branding and consumer-brand relationship therefore suggest the following hypothesis:

\section{H2: The more favorable the perceived brand experiences, the stronger the consumer-brand relationship.}

Following the relationship theory in the literature, Fournier (1998) and de Chernatony and Segal-Horn (2003) concluded that a strong consumer-brand relationship adds to the value of a brand. From a communication theory perspective, Duncan and Moriarty (1998) further suggested that a multi-level integrated communication program directed at all stakeholders concerned increases the interactivity between consumers and a firm that finally strengthens consumer-firm relationships and adds to brand value. A number of subsequent studies examined the effects of a consumer-brand relationship on various marketing outcomes. For example, Thomson et al. (2005) verified that consumers' affective attachments (a concept similar to consumer-brand relationship) to brands affect brand loyalty and price premium, two measures of brand equity. Furthermore, Ashworth et al. (2009) investigated the influences of consumer-brand relationships to a number of marketing outcomes such as perceived quality, attitude favorability, word-of-mouth etc. Huang et. al. (2014) examined how brand relationship quality affected brand loyalty. Thus,

\section{H3: The stronger the consumer-brand relationship, the higher the perceived brand equity.}

While various studies have been conducted to classify different types of relationship along different measurement dimensions, divergent views could be found concerning how these dimensions affect relationship formation and strength (Fournier 2009). It seems that more studies agree to the relative importance of affective benefits compared to utilitarian benefits in forming the strong consumer-brand relationship (e.g. Berry 2000, Gobe 2001, Holt 2004, Thomson et al. 2005, Park et al. 2008). However, a few studies show a different view. For example, Asworth et al. (2009) indicated that utilitarian brand attributes may contribute to strong consumer-brand relationships. Leung et. al. (2014) arrived at the conclusion that utilitarian brand relationships may contribute more to brand equity than affective relationships. Therefore,

H4: Both utilitarian and affective dimensions contribute significantly to consumer-brand relationship strength. 


\section{Research Method}

\section{Sample and Data Collection}

Lovelock (1983) and Bowen (1990) proposed that different services might be classified by the degree of customization. Subsequent research confirmed that services across different cultures could be grouped by two dimensions: standardization/customization and person/object (Cunningham et al. 2004, Cunningham and Young 2006, Cunningham et al. 2009). Therefore, standardized vs. customized services were chosen to define scope for this research. Two service products and three brand stimuli for each service category were selected for this study. The two service products chosen were fast foods which represent standardized services, and banking services which represent customized services. The two service products were also selected to reflect the different relationship types displayed in the consumer-brand relationship map developed by Fournier (2009). The relationship mapping is defined by relationship strength (from superficial/ weak to intense/strong) and relationship rewards (from socio-affective to utilitarian/functional rewards) (Fournier 2009, Fournier and Avery 2011). Therefore, the fast food category should have weaker relationships with consumers, but higher affective benefits perceived while the banking services should entail stronger consumer relationships and higher utilitarian rewards. The six brand stimuli were McDonalds, Cafe De Coral and Fairwood for the fast food category (both Cafe De Coral and Fairwood are Hong Kong based chains); and the Hong Kong Bank, Bank of China and Bank of East Asia for the banking category. One of the six brands was randomly assigned to each respondent to answer a selfadministered questionnaire.

The model in this study was tested by using a student sample recruited from a university in Hong Kong. A total of 333 responses were collected from the university hostels, with 169 respondents for the fast food sample and 164 respondents for the banking sample. Given a self-administrated questionnaire, each sample respondent was randomly assigned with one of the six brands in this study and was asked to answer the questionnaire with reference to the assigned brand. There were two reasons for using a student sample as recommended by Yoo et al. (2000). First, it was observed that banks and fast food outlets were located either inside or close to all university campuses in Hong Kong and hence students had been considered as primary consumers for these two services. Second, a student sample selected from a relatively homogenous population is most suitable for theory testing (Yoo et al. 2000).

\section{Measurement Development}

Based on the study by Grace and O'Cass (2004), brand experiences were measured by three indicators: core service performance, service employee behaviors and servicescape. Each indicator was measured by multiple items. An example measurement item for core service performance was "Brand $\mathrm{X}$ is reliable", resulting a 7-item measure for core service performance, a 7-item measure for employee behaviors and an 8-item measure for servicescape. The description of all measurement items for brand experiences is shown in Table 1. 
Table 1. Measurement Items for Consumer-Brand Experiences

\begin{tabular}{|c|c|c|}
\hline Construct & $\begin{array}{l}\text { Measurement } \\
\text { Indicators }\end{array}$ & Description of Measurement Items \\
\hline \multirow[t]{3}{*}{$\begin{array}{l}\text { Consumer- } \\
\text { Brand } \\
\text { Experiences }\end{array}$} & $\begin{array}{l}\text { Core Service } \\
\text { performance }\end{array}$ & $\begin{array}{l}\text { - Brand X suits my needs } \\
\text { - Brand X is reliable } \\
\text { - Brand X offers good core service } \\
\text { - Brand X offers quality core service } \\
\text { - Brand X is superior } \\
\text { - The quality of Brand X is consistent }\end{array}$ \\
\hline & $\begin{array}{l}\text { Service } \\
\text { Employee } \\
\text { Behaviors }\end{array}$ & $\begin{array}{l}\text { - The employees of Brand X provide prompt service } \\
\text { - The employees of Brand X are willing to help me } \\
\text { - The employees of Brand X are never too busy for me } \\
\text { - I can trust employees of Brand X } \\
\text { - I feel safe in conducting transactions through Brand X } \\
\text { - The employees of Brand X are polite } \\
\text { - The employees of Brand X give personal attention }\end{array}$ \\
\hline & Servicescape & $\begin{array}{l}\text { - Brand X has up-to-date facilities } \\
\text { - The facilities of Brand X are attractive } \\
\text { - Brand X has neat employees } \\
\text { - The facility suits service type } \\
\text { - } \text { Braverage, the waiting time in Brand X is long } \\
\text { product) } \\
\text { - The lighting of Brand } X \text { is suitable and comfortable } \\
\text { - The environment of Brand X provides a warm atmosphere }\end{array}$ \\
\hline
\end{tabular}

Note: All measurement items are measured by 7-point Likert scales with 1=strongly disagree and $7=$ strongly agree.

Source: Author's estimations.

Measures for consumer-brand relationship and brand equity were developed from the literature. Consumer brand relationship was conceived as a second order construct comprising a utilitarian and an affective dimension (Leung et al. 2014). Following the works of Fournier (1998), three indicators were used to measure the utilitarian dimension (i.e. commitment, intimacy and partner quality) and another three indicators to measure the affective dimension (i.e. love/passion, self-connection and interdependence). Each indicator was a multi-item measure and the measurement items for each indicator (refer to Table 2) were developed from a number of studies including Heide (1994), Sirgy et al. (1997), Fletcher et al. (2000), Thorbjornsen et al. (2002), Aaker et al. (2004) and Reast (2005). An example item for the multi-item measure of love/passion was "I deeply love brand $X "$ ".

Brand equity was measured by two indicators, brand uniqueness and price premium, adopted from Netemeyer et al. (2004) and each indicator was a fouritem measure as shown in Table 2. An example item for measuring brand uniqueness was "Brand $X$ is distinct from other brands of fast food/banking services". The response categories for each measurement item ranged between 1 (strongly disagree) and 7 (strongly agree). 
Table 2. Measurement Items for Consumer-Brand Relationship and Brand Equity

\begin{tabular}{|c|c|c|}
\hline Construct & $\begin{array}{l}\text { Measurement } \\
\text { Indicators }\end{array}$ & Description of Measurement Items \\
\hline \multirow[t]{6}{*}{$\begin{array}{l}\text { Consumer- } \\
\text { Brand } \\
\text { Relationship }\end{array}$} & $\begin{array}{l}\text { Inter- } \\
\text { dependence }\end{array}$ & $\begin{array}{l}\text { - I can easily adapt to using a new brand in place of Brand X } \\
\text { - I need only to spend minimal efforts to switch to using other brands } \\
\text { - I am likely to try new product/service provided by Brand }\end{array}$ \\
\hline & Self-Connection & $\begin{array}{l}\text { - People who use Brand X are much more like me than users of other brands } \\
\text { - I can identify myself with those people who use Brand X } \\
\text { - I am very much like the typical person who prefers Brand X over other (product) brands } \\
\text { - The image of Brand X is highly consistent with how I see myself }\end{array}$ \\
\hline & Love/Passion & $\begin{array}{l}\text { - I feel my relationship with Brand X is exclusive and special } \\
\text { - I have feelings for Brand X that I do not have for many other brands in general } \\
\text { - I deeply love Brand X } \\
\text { - I always think of Brand X in my mind with pleasure }\end{array}$ \\
\hline & Intimacy & $\begin{array}{l}\text { - I would feel comfortable sharing detailed personal information with the employees of Brand X } \\
\text { - Brand X really understands my needs } \\
\text { - I'd feel comfortable describing Brand X to someone who is not familiar with it } \\
\text { - I am familiar with the range of products and services Brand X offers } \\
\text { - I am very knowledgeable about Brand X }\end{array}$ \\
\hline & $\begin{array}{l}\text { Brand Partner } \\
\text { Quality }\end{array}$ & $\begin{array}{l}\text { - I can always count on Brand X to do what's best } \\
\text { - If Brand X makes a mistake, it will try its best to make up for it } \\
\text { - I know I can hold Brand X accountable for its actions } \\
\text { - Brand X is reliable } \\
\text { - Given my image of Brand X, letting me down would surprise me } \\
\text { - A service failure would be inconsistent with my expectations of Brand X }\end{array}$ \\
\hline & Commitment & $\begin{array}{l}\text { - I am very loyal to Brand X } \\
\text { - I am willing to make small sacrifices in order to keep using Brand X } \\
\text { - I am willing to postpone my purchase if Brand X site is temporarily unavailable } \\
\text { - I would stick with Brand X even if it let me down once or twice } \\
\text { - I am so happy with Brand X that I no longer feel the need to watch out for other (product) alternatives } \\
\text { - I am likely to continue the using of Brand X for another year }\end{array}$ \\
\hline
\end{tabular}




\begin{tabular}{|c|c|c|}
\hline \multirow[t]{2}{*}{ Brand Equity } & $\begin{array}{l}\text { Brand } \\
\text { Uniqueness }\end{array}$ & $\begin{array}{l}\text { - Brand X is distinct from others brands of (product) } \\
\text { - Brand X really stands out from other brands of (product) } \\
\text { - Brand X is very different from other brands of (product) }\end{array}$ \\
\hline & Price Premium & $\begin{array}{l}\text { - The price of Brand X would have to go up quite a bit before I would switch to another brand of (product) } \\
\text { - I am willing to pay a higher price for Brand X than for other brands of (product) } \\
\text { I am willing to pay a lot more for Brand X than other brands of (product) } \\
\text { - I a willing to pay } \% \text { more for Brand X over other brands of product: } 0 \%, 5 \%, 10 \%, 15 \%, 20 \%, 25 \%, 30 \% \text { or more }\end{array}$ \\
\hline
\end{tabular}

Note: All measurement items are measured by 7 -point Likert scales with $1=$ strongly disagree and $7=$ strongly agree.

Source: Author's estimations. 


\section{Data Analysis}

The factor structure of each key construct was first analyzed by exploratory factor analysis (EPA) and Cronbach's alpha coefficients so as to examine whether the data of the two samples, one for fast food and the other for banking, could be pooled together as a single data set for further analysis (Nunnally and Bernstein 1994, Hair et al. 2010). Measurement items with rotated factor loadings $\geq 0.4$ were considered as a factor for measuring a construct and Cronbach $\alpha$ was used to examine the internal consistency. The relationships among the constructs in the conceptual model were estimated by structural equation modeling (SEM) based on Amos 19 and maximum likelihood method. The two-step approach suggested by Anderson and Gerbing (1988) was employed to first "fix" the measurement model before estimating the structural model. Since this study posited the consumer-brand relationship as a second order construct comprising utilitarian and affective dimension, the measurement model for this second order construct was first validated by confirmatory factor analysis (CFA) before the parameters of the structural model were estimated. Multiple indices were used to assess the model fit as suggested by Shook et al. (2004). The model fit was assessed by five indices including overall model fit measures (RMSEA and SRMR), incremental fit measures (TLI and CFI) and parsimonious fit measure (normed chi-square $\chi 2 / \mathrm{df}$ ). The commonly used indices such as GFI and AGEI were not reported in this study due to their upward bias with increase in sample size (Sharma et al. 2005, Martinez-Lopez et al. 2013). The cut-off points were 0.6 to 0.8 for SRMR and RMSEA, 0.95 for TLI and CFI, and between 2 to 5 for $\chi 2 / \mathrm{df}(\mathrm{Hu}$ and Bentler 1999, Hooper et al. 2008).

\section{Findings}

\section{Exploratory Factor Analysis (EPA) Results}

The Cronbach's $\alpha$ for each indicator was above the 0.7 threshold level and the factor structure of each construct was similar across two samples (fast food and banking). The results of all EPA and reliability analyses provided preliminary evidence that the pattern of measurement indicators (i.e. the factor structure) for all key constructs in the conceptual model in Figure 1 was similar across the fast food and banking samples and hence the data of the two samples could be pooled together as a single data set for data analysis.

\section{Confirmatory Factor Analysis (CFA) Results}

CFA was used to confirm the second order structure of consumer-brand relationship defined by the utilitarian and the affective relationship dimensions in this study (Figure 1). Each relationship dimension was measured by three indicators and each indicator was a summated rating scale of the measurement 
items described in Table 2. The results confirmed the second order structure of consumer-brand relationship. The values of the overall model fit indices for SRMR, RMSEA, TLI, CFI and $\chi^{2} / \mathrm{df}$ are 0.02, 0.06, 0.989, 0.994 and 2.285, which are in general within the required cut-off points. The patterns of standardized loadings were similar across the two samples (fast food and banking). Together with the results of the EFA and reliability analyses, it was justified to combine the data of the two samples together as a single data set for estimating the path coefficients of the structural model.

\section{Parameter Estimation for the Structural Model}

Referring to Figure 2, the proposed model in this study is a partial mediation model with both direct effects of brand experiences on brand equity (i.e. path coefficient $a \neq 0$ ) and indirect effects of brand experiences on brand equity via consumer-brand relationship. However, a competing model, the full mediation model, exists when the path coefficient $a=0$. That is, there is no direct effect between brand experiences and brand equity. The findings are indicated in Table 3.

A model comparison test was performed to compare the proposed model (partial mediation) in this study and the competing model (full mediation). The results of the chi-square difference test showed that the full mediation model was significantly different from the partial mediation model $(\chi 2$ difference value $=11.686, \mathrm{df}=1$ and $\mathrm{p}<0.001)$. The partial mediation model possessed better explanatory power than the full mediation model when examining the model fit indices and the path loadings, and hence the partial mediation model was retained in this study. Therefore, the consumer-brand relationship partially mediates the relationship between brand experiences and brand equity.

The respective model fit indices for the partial mediation model were 0.041, 0.07, 0.976, 0.984 and 2.61 for SRMR. RMSEA, TLI, CFI and normed chi-square $(\chi 2 / \mathrm{df})$. All selected indices were within the threshold limits (Shook et al. 2004). As shown in Table 3, all standardized loadings of the structural relationships in the partial mediation model are significant at $\mathrm{p}<0.01$. It should be noted that the standardized loading for the direct effect from brand experiences to brand equity is much weaker than the standardized loadings for the indirect effect from brand experiences to brand equity via brand relationships (0.254 vs. 0.802 and 0.708). This highlights the important mediating role of consumer-brand relationship in connecting brand experiences and brand equity. 
Figure 2. The Partial Mediation Model $(a \neq 0)$ vs. the Full Mediation Model $(a=0)$

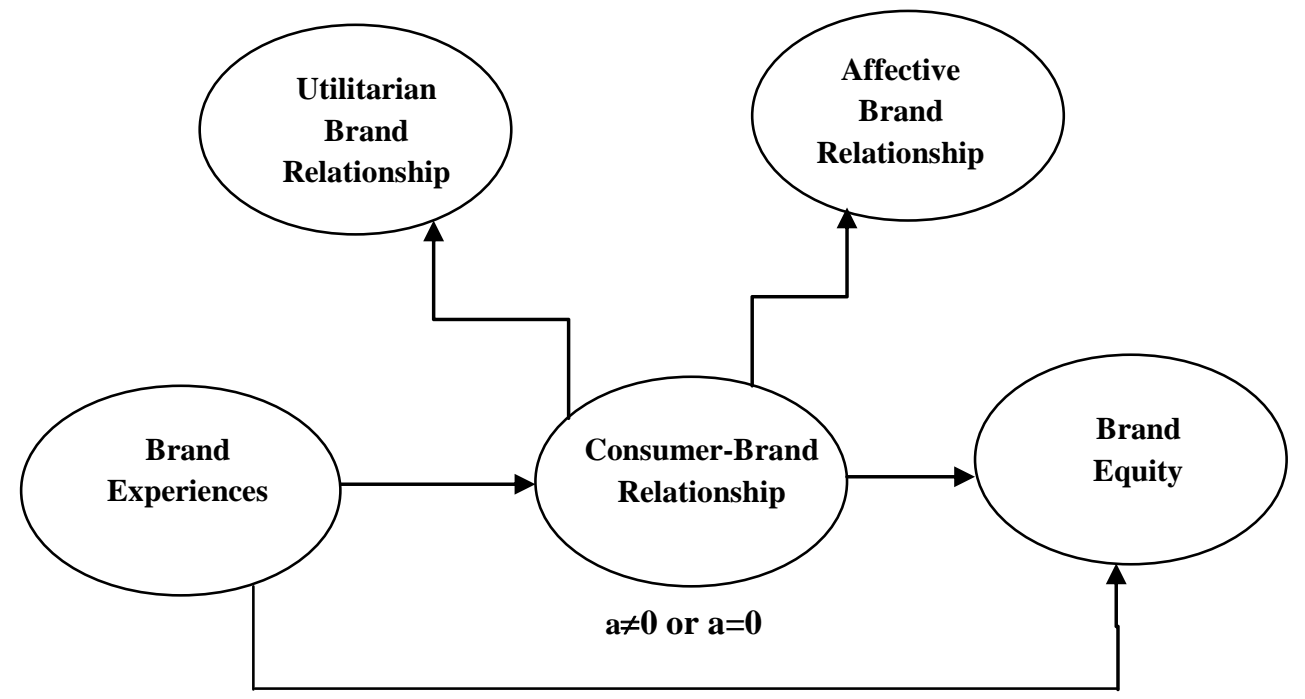

Source: By author.

Table 3. Standardized Loadings and Model Fit Indices for Partial Mediation Model $(a \neq 0)$ and Full Mediation Model $(a=0)(N=333)$

\begin{tabular}{|c|c|c|}
\hline $\begin{array}{c}\text { Structural Relationships and } \\
\text { Model Fit Indices }\end{array}$ & $\begin{array}{c}\text { Standardized Loadings } \\
\text { for Partial Mediation } \\
\mathbf{a \neq 0}\end{array}$ & $\begin{array}{c}\text { Standardized } \\
\text { Loadings for Full } \\
\text { Mediation (a=0) }\end{array}$ \\
\hline $\begin{array}{l}\text { Brand Experiences } \rightarrow \\
\text { Brand Equity (H1a and H1b) }\end{array}$ & 0.254 & 0.000 \\
\hline $\begin{array}{l}\text { Brand Experiences } \rightarrow \\
\text { Brand Relationship (H2) }\end{array}$ & 0.802 & 0.809 \\
\hline $\begin{array}{l}\text { Brand Relationship } \rightarrow \\
\text { Brand Equity (H3) }\end{array}$ & 0.708 & 0.923 \\
\hline $\begin{array}{l}\text { Brand Relationship } \rightarrow \\
\text { Affective Relationship (H4) }\end{array}$ & 0.975 & 0.976 \\
\hline $\begin{array}{l}\text { Brand Relationship } \rightarrow \\
\text { Utilitarian Relationship (H4) }\end{array}$ & 0.998 & 0.998 \\
\hline $\boldsymbol{\chi 2}$ (df) & $97.17(37)$ & $108.9(38)$ \\
\hline Probability Level & 0.000 & 0.000 \\
\hline SRMR & 0.043 & 0.048 \\
\hline RMSEA & 0.070 & 0.075 \\
\hline TLI & 0.974 & 0.979 \\
\hline CFI & 0.983 & 2.865 \\
\hline $\boldsymbol{\chi 2 / d f}$ & 2.626 & 670 \\
\hline
\end{tabular}

Note: All standardized loadings (except the one between brand experiences and brand equity which was constrained to zero in the full mediation model) in the table were significant at $\mathrm{p}<0.01$.

Source: Author's estimations. 


\section{Validity and Reliability Assessment for the Partial Mediation Model}

With reference to Table 4, reliability and validity of the proposed partial mediation model were evaluated by examining the composite reliabilities (ranged between 0.76 and 0.98), average variances extracted (AVE) (ranged between 0.67 and 0.97 ) and the standardized loadings (ranged between 0.254 and 0.998) of all the key constructs in the proposed model (Bagozzi and Yi 1988). The respective cut-off points are 0.7, 0.5 and 0.5 (Bagozzi and Yi 1988, Hair et al. 2010) and the proposed model in general observed these criteria.

Table 4. Composite Reliabilities and Variances Extracted for the Key Constructs in the Partial Mediation Model $(N=333)$

\begin{tabular}{|l|c|c|}
\hline \multicolumn{1}{|c|}{ Constructs } & Composite Reliabilities & $\begin{array}{c}\text { Variances } \\
\text { Extracted }\end{array}$ \\
\hline Brand Experiences & 0.90 & 0.64 \\
\hline Consumer-Brand Relationship & 0.98 & 0.97 \\
\hline Affective Relationship & 0.86 & 0.67 \\
\hline Utilitarian Relationship & 0.96 & 0.69 \\
\hline Brand Equity & 0.76 & 0.67 \\
\hline
\end{tabular}

Source: Author's estimations.

\section{Hypotheses Testing}

The four proposed hypotheses in this study were tested by examining the results in Table 3 together with the overall model fit indices. As all standardized loadings are significant at $\mathrm{p}<0.01$ and the selected overall model fit indices were within the threshold limits, all four hypotheses were verified in this study. Consumer-brand relationship significantly mediates the relationship between brand experiences and brand equity and the effect is much stronger than the direct effect from brand experiences to brand equity. This also confirms the co-creative nature of brand experiences evolvement involving the interactions between the consumers and the brand throughout the brand leveraging process.

\section{Standardized Loadings for the Proposed Model}

Brand experiences in this study were measured by core service performance, employee behaviors and servicescape. Their respective path coefficients were $0.932,0.844$ and 0.847 and thus it seemed that core service performance contributed to brand experiences slightly more than the other two indicators. However, both utilitarian and affective dimensions of brand relationship contributed equally to consumer-brand relationship (0.998 vs. 0.975 , refer to Table 3 ). Path coefficients of individual measurement indicators for utilitarian relationship dimension ( 0.988 for partner quality, 0.924 for intimacy and 0.939 for commitment) were slightly higher than those of affective relationship dimension $(0.745$ for interdependence, 0.804 for selfconnection and 0.929 for love/passion). It appeared that the utilitarian attributes 
for both service categories in this study were slightly more significant than the affective attributes in forming the consumer-brand relationship. Standardized loadings for brand equity are 0.839 for brand uniqueness and 0.735 for price premium.

\section{Regression Analysis}

Using the two brand equity measures (i.e. brand uniqueness and price premium) as dependent variables, the relative contribution of various indicators for brand experiences and brand relationships to brand equity was analyzed by regression. The results are shown in Table 5.

Table 5. Regression Results using Brand Uniqueness and Price Premium as Dependent Variables

\begin{tabular}{|l|c|c|c|c|}
\hline \multicolumn{1}{|c|}{ Independent Variables } & $\begin{array}{c}\text { Brand } \\
\text { Uniqueness }\end{array}$ & $\begin{array}{c}\text { Statistical } \\
\text { Significance }\end{array}$ & $\begin{array}{c}\text { Price } \\
\text { Premium }\end{array}$ & $\begin{array}{c}\text { Statistical } \\
\text { Significance }\end{array}$ \\
\hline Inter-dependence & $*$ & $*$ & $*$ & $*$ \\
\hline Self-connection & $*$ & $*$ & 0.177 & $* *$ \\
\hline Love/Passion & $0.207 * * *$ & $* *$ & $*$ & $*$ \\
\hline Intimacy & $*$ & $*$ & 0.243 & $* *$ \\
\hline Brand Partner quality & 0.258 & $* *$ & $*$ & $*$ \\
\hline Commitment & 0.222 & $* *$ & 0.248 & $* *$ \\
\hline Core Service Performance & $*$ & $*$ & $*$ & $*$ \\
\hline Service Employees & 0.181 & $* *$ & $*$ & $*$ \\
\hline Servicecapes & $*$ & $*$ & $*$ & $*$ \\
\hline R Square & 0.593 & $* *$ & 0.447 & $* *$ \\
\hline
\end{tabular}

Note: *Variable that was insignificant and excluded in the regression analysis.

$* * \mathrm{p}<0.01$

$* * *$ Standardized coefficient.

Source: Author's estimations.

For brand uniqueness, brand partner quality $(0.258$, a utilitarian relationship indicator), commitment (0.222, a utilitarian relationship indicator) and brand love/passion (0.207, an affective relationship indicator) contributed significantly to brand equity. Service employees seemed to be the main determinant of customer experiences $(0.181)$ that enhanced brand equity (directly or indirectly via consumer-brand relationship as confirmed in the conceptual model in this study using structural analysis). However, for price premium, only two utilitarian relationship indicators (i.e. 0.243 for intimacy and 0.248 for commitment) and one affective relationship indicator (i.e. 0.177 for self-connection) significantly affected brand equity. This further validated the mediating role of consumer-brand relationship in the conceptual model proposed previously. It seemed also that the utilitarian brand relationship contributed more to brand equity than the affective dimension of brand relationship. 


\section{Discussion}

This study attempted to examine the effects of brand experiences on brand equity via consumer-brand relationship and confirmed the significant mediating role of consumer-brand relationship in contributing to brand equity. The research results demonstrated that service employees, among the various consumer experiences with a service, were the most important factor that affected brand equity directly or indirectly via consumer-brand relationship. This shows the co-creative nature of brand experiences in enhancing brand equity through the interactions between the consumers and the various touch points with a service organization such as employees and servicescapes during the service delivery. Both the utilitarian and affective dimensions of brand relationship contribute to brand equity for services. However, the utilitarian dimension seems contributing more to brand equity than the affective dimension. This finding is very different from many previous studies that suggest the importance of the affective dimension in developing brand equity (e.g. Berry 2000, Thomson et al. 2005, Heath et al. 2006, Zambardino and Goodfellow 2007).

\section{Marketing Implications}

Given that the previous studies call for a focus on developing affective relationships to enhance brand equity (Zambardino and Goodfellow 2007, Batra et al. 2012, Albert and Merunka 2013), this research gives a word or caution to the marketers that developing utilitarian brand relationships should be viewed at least as important as affective relationships. Consumers of fast food (a standardized service) and banking (a customized service) seem to emphasize the functional aspects of services more than the emotional dimensions. This study suggests that marketers should put more efforts on developing utilitarian relationships through customer experiences for enhancing quality, commitment and intimacy to increase brand equity.

This research also suggests that service employees seem to be the most important factor to determine customer experiences with a service. For the two service categories in this study, employees are the ones that perform the core services and manage the service environment. It is therefore important to recruit the right people and to provide adequate training to employees so that distinct experiences could be created for consumers.

\section{Limitations and Future Research Directions}

Several research limitations are observed. The present research is limited to only two service categories and six brands and is confined to the context of dyadic relationships. While the research design attempted to increase internal validity, it was at the expense of trading-off external validity. This study may also incur measurement errors due to a number of reasons such as the adequacy of the sampling plan, questionnaire collection and the domain of measurement 
items chosen. Overall, the measurement accuracy was within the acceptable limits as steps were taken to ensure the validity and the reliability of measures adopted. Finally, the present research did not take into account the cultural differences that might affect the applicability of the conceptual model in different countries.

There are a number of areas that require further research pursuit. For instance, it is pointed out by de Chernatony and Segal-Horn (2003) that organizational factors such as corporate values/culture and employee training are important variables to meet service promises and to determine perceived quality and brand value. Little research has been conducted to examine how various organizational factors may influence consumers' perceived brand relationship and brand value. In addition, further research should include more service categories and address the cultural differences that might affect the generalizability of the proposed model in this study.

Furthermore, the present study is confined to dyadic consumer-brand relationships. However, the interactions between a brand and a consumer may involve a complex web of relationships (Muntz and O'Guinn 2001). It is not known how the branding efforts can be capitalized in enhancing this web of relationships and in attaining brand equity.

\section{Conclusions}

The present research confirms that brand equity is the result of a cocreation process between a service organization and its consumers via developing a consumer-brand relationship to connect brand experiences with brand equity. Service employees, among various touch points with consumers in a service process, are the major determinant of customer experiences. In contrary to the previous studies that point to the importance of developing affective relationships, building utilitarian consumer-brand relationships, as shown in this study, is as important as, if not more important than, affective brand relationships to foster brand equity. Marketers should pay more attention to the utilitarian dimensions of brand relationships.

\section{References}

Aaker DA (1991) Managing Brand Equity: Capitalizing on the Value of a Brand Name. The Free Press.

Aaker DA (1996) Measuring brand equity across products and markets. California Management Review 38(3): 102-120.

Aaker JL (1997) Dimensions of brand personality. Journal of Marketing Research 34(3): 347-356.

Aaker J, Fournier S, Brasel SA (2004) When good brands do bad. Journal of Consumer Research 31(June): 1-16.

Albert N, Merunka D (2013) The role of brand love in consumer-brand relationships. Journal of Consumer Marketing 30(3): 258-266. 
Anderson JC, Gerbing DW (1988) Structural equation modeling in practice: a review and recommended two-step approach. Psychological Bulletin 103(3): 411-423.

Ashworth L, Dacin P, Thomson M (2009) Why on earth do consumers have relationships with marketers? Toward understanding the functions of brand relationship. In MacInnis DJ, Park CW, Priester JR, Sharpe ME (Edn.) Handbook of Brand Relationships, pp. 82-106.

Bagozzi RP, Yi Y (1988) On the evaluation of structural equation models. Journal of the Academy of Marketing Science 16(1): 74-94.

Batra R, Aaron A, Bagozzi RP (2012) Brand love. Journal of Marketing 76(2): 1-16.

Berry L (2000) Cultivating service brand equity. Journal of Academy of Marketing Science 28(1): 128-137.

Bharadwaj SG, Varadarajan PR, Fahy J (1993) Sustainable competitive advantage in service industries: a conceptual model and research propositions. Journal of Marketing 57(October): 83-99.

Bowen J (1990) Development of a taxonomy of services to gain strategic marketing insights. Journal of the Academy of Marketing Science 18(1): 43-49.

Bowen J (1990) Development of a taxonomy of services to gain strategic marketing insights. Journal of the Academy of Marketing Science 18(1): 43-49.

Brakus JJ, Schmitt BH, Zarantonello L (2009) Brand experience: what is it? How is it measured? Does it affect loyalty? Journal of Marketing 73(May): 52-68.

Chang PL, Chieng MH (2006) Building consumer-brand relationship: a cross-cultural experiential view. Psychology \& Marketing 23(11): 927-959.

Cunningham LF, Young CE, Ulaga W, Lee M (2004) Consumer views of service classifications in the USA and France. Journal of Services Marketing 18(6): 421-432.

Cunningham LF, Young CE (2006) Customer perceptions of service dimensions: cross-cultural analysis and perspective. International Marketing Review 23(2): 192-210.

Cunningham LF, Young CE, Gerlach F (2009) A comparison of consumer views of traditional services and self-service technologies. Journal of Services Marketing 23(1): 11-23.

de Chernatony L, Segal-Horn S (2003) The criteria for successful services brands. European Journal of Marketing 37(7/8): 1095-1118.

Duncan T, Moriarty SE (1998) A communication-based marketing model for managing relationships. Journal of Marketing 62(2): 1-13.

Fletcher GJO, Simpson JA, Thomas G (2000) The measurement of perceived relationship quality components: a confirmatory factor analytic approach. Personality and Social Psychology Bulletin 26(3): 340-354.

Fournier S (1998) Consumers and their brands: developing relationship theory in consumer research. Journal of Consumer Research 24(4): 343-373.

Fournier S (2009) Lessons learned about consumers' relationships with their brands. In MacInnis DJ, Park CW, Priester JR, Sharpe ME (Edn.) Handbook of Brand Relationships, pp. 7-23.

Fournier S, Avery J (2011) Putting the "relationship" back into CRM. MIT Sloan Management Review 52(3): 63-71.

Gobe M (2001) Emotional Branding: The New Paradigm for Connecting Brands to People. Allworth Press.

Grace D, O'Cass A (2004) Examining service experiences and post-consumption evaluation. Journal of Services Marketing 18(6): 450-461.

Hair JF, Black WC, Babin BJ, Anderson RE (2010) Multivariate Data Analysis ( $^{\text {th }}$ Edn.). NJ: Prentice-Hall. 
Heath R, Brandt D, Haian A (2006) Brand relationship: strengthened by emotion, weakened by attention. Journal of Advertising Research (December): 410-419.

Heide JB (1994) Interorganizational governance in marketing channels. Journal of Marketing 58(1): 71-85.

Holt DB (2004) How Brands Become Icons: The Principles of Cultural Branding. Harvard Business School Press.

Hooper D, Coughlan J, Mullen MR (2008) Structural equation modelling. The Electronic Journal of Business Research Methods 6(1): 53-60.

Hu LT, Bentler PM (1999) Cutoff criteria for fit indexes in covariance structure analysis: conventional criteria versus new alternatives. Structural Equation Modeling 6: 1-55.

Huang CC, Fang SC, Huang SM, Chang SC, Fang SR (2014) The impact of relational bonds on brand loyalty: the mediating effect of brand relationship quality. Managing Service Quality 24(2): 184-204.

Iglesias O, Singh JJ, Batista-Foguet JM (2011) The role of brand experience and affective commitment in determining brand loyalty Journal of Brand Management 18(8): 570-582.

Ismail AR, Melewar TC, Lim L, Woodside A (2011) Customer experiences with brands: literature review and research directions. The Marketing Review 15(5): 795-825.

Keller KL (1993) Conceptualizing, measuring and managing customer-based brand equity. Journal of Marketing 57(January): 1-22.

Keller KL (2001) Building consumer-based brand equity. Marketing Management 10(2): $15-20$.

Keller KL (2003) Brand synthesis: the multidimensionality of brand knowledge. Journal of Consumer Research 29(March): 595-600.

Keller KL (2013) Strategic Brand Management: Building, Measuring, and Managing Brand Equity ( $4^{\text {th }}$ Edn.). Boston: Pearson.

Lee HJ, Kang MS (2012) The effect of brand experience on relationship quality. Academy of Marketing Studies Journal 16(1): 87-98.

Leung LC, Bougoure US, Miller KW (2014) The effects of utilitarian and affective brand relationships on brand consideration. Journal of Brand Management 21(6): 469-484.

Lovelock C (1983) Classifying services to gain strategic marketing insights. Journal of Marketing 47(Summer): 9-20.

Maclinnis DJ, Park CW, Priester J (2009) Why brand relationships? In MacInnis DJ, Park CW, Priester JR, Sharpe ME (Edn.) Handbook of Brand Relationships, pp. ix-xxi.

Martinez-Lopez FJ, Gazquez-Abad JC, Cousa CMP (2013) Structural equation modelling in marketing and business research: critical issues and practical recommendations. European Journal of Marketing 47(1/2): 115-152.

McCracken G (1993) The value of the brand: an anthropological perspective. In Aaker DA, Biel AL (Edn.) Brand Equity and Advertising: Advertising's Role in Building Strong Brands. Lawrence Erlbaum Associates, pp. 125-139.

Merz MA, He Y, Vargo SL (2009) The evolving brand logic: a service-dominant logic perspective. Journal of Academy of Marketing Science 37: 328-144.

Morgan-Thomas A, Veloutsou C (2013) Beyond technology acceptance: brand relationship and online brand experience. Journal of Business Research 66(1): 21-27.

Muntz AM Jr., O'Guinn TC (2001) Brand community. Journal of Consumer Research 27(March): 412-432. 
Netemeyer RG, Krishnan B, Pullig C, Wang G, Yagei M, Dean D, Ricks J, Wirth F (2004) Developing and validating measures of facets of customer-based brand equity. Journal of Business Research 57: 209-224.

Nunnally JC, Bernstein IH (1994) Psychometric Theory ( $3^{\text {rd }}$ Edn.). McGraw-Hill.

Pappu R, Quester PG, Cooksey RW (2005) Consumer-based brand equity: improving the measurement-empirical evidence. Journal of Product \& Brand Management 14(3): 143-154.

Park CW, MacInnis DJ, Priester J (2008) Brand Attachment: Constructs, Consequences and Causes. Boston: Delft.

Prahalad CK, Ramaswamy V (2000) Co-opting customer experience. Harvard Business Review (Jan-Feb): 79-87.

Prahalad CK, Ramaswamy V (2004) Co-creation experiences: the next practice in value creation. Journal of Interactive Marketing 18(3): 5-14.

Reast JD (2005) Brand trust and brand extension acceptance: the relationship. Journal of Product and Brand Management 14(1): 4-13.

Schmitt BH (1999) Experiential Marketing. Journal of Marketing Management 15: 53-67.

Sharma S, Mukherjee S, Kumar A, Dillon W (2005) A Simulation study to investigate the use of cutoff values for assessing model fit in covariance structure models. Journal of Business Research 58(7): 863-1008.

Shook CL, Ketchen DJ Jr., Hult TM, Kacmar KM (2004) An assessment of the use of structural equation modeling in strategic management research. Strategic Management Journal 25: 397-404.

Sirgy MJ, Grewal D, Mangleburg TF, Park J, Chon KS, Claiborne CB, Johar JS, Berkman $\mathrm{H}$ (1997) Assessing the predictive validity of two methods of measuring self-image congruence. Journal of the Academy of Marketing Science 25(3): 229-241.

Smit E, Bronner F, Tolboom M (2007) Brand relationship quality and its value for personal contact. Journal of Business Research 60: 627-633.

Sweeney JC, Chew M (2002) Understanding consumer service brand relationships: a case study approach. Australasian Marketing Journal 10(2): 26-43.

Thompson CJ, Rindfleisch A, Arsel Z (2006) Emotional branding and the strategic value of the doppelganger brand image. Journal of Marketing 70(January): 50-64.

Thomson M, MacInnis DJ, Park CW (2005) The ties that bind: measuring the strength of consumers' emotional attachments to brands. Journal of Consumer Psychology 15(1): 77-91.

Thorbjornsen H, Supphellen M, Nysveen H, Pedersen PE (2002) Building brand relationships online: a comparison of two interactive applications. Journal of Interactive Marketing 16(3): 17-34.

Vargo SL, Lusch RF (2004) Evolving to a new dominant logic for marketing. Journal of Marketing 68(1): 1-17.

Veloutsou C (2007) Identifying the dimensions of the product-brand and consumer relationship. Journal of Marketing Management 23(1/2): 7-26.

Yoo B, Donthu N, Lee S (2000) An Examination of selected marketing mix elements and brand equity. Journal of Academy of Marketing Science 28(2): 195-211.

Yoo B, Donthu N, Lee S (2001) Developing and validating a multidimensional consumer-based brand equity scale. Journal of Business Research 52(1): 1-14.

Zambardino A, Goodfellow J (2007) Being "affective" in branding. Journal of Marketing Management 23(1-2): 27-37.

Zarantonello L, Schmitt BH (2010) Using the brand experience scale to profile consumers and predict consumer behavior. Journal of Brand Management 17(7): $532-540$. 
